\title{
Self Discrepancy pada Roleplayer K-Pop pada Komunitas Entertaiment ' $X$ ' di Twitter
}

\author{
Yenisca Juniar ${ }^{*}$, Eni Nuraeni Nugrahawati \\ Prodi Psikologi, Fakultas Psikologi, Universitas Islam Bandung, Indonesia. \\ yenisca@yahoo.com, eni.nuraeni@unisba.ac.id
}

\begin{abstract}
Roleplay is defined as an activity where someone parodies their idol. A roleplayer plays a character of his own. In this game everyone does not know the real identity of each, so someone must make their own character. In this community there are several players who use male sex characters even though in the real world he is a woman. Most of them are aged 18-24 years with jobs as students and private employees. Roleplayer in this study has been playing in this community for more than five years and the original self is very different from the virtual self. In these conditions, there is a mismatch of perceptions between Actual Self, Ideal Self, Ought Self and Virtual Self, this is referred to as Self Discrepancy (Higgins, 2000). This research uses descriptive analysis method to find out how Self Discrepancy in K-Pop Rollayer in the Entertiment Community ' $\mathrm{x}$ '. The measurement tool uses a questionnaire (SDQ) Self Discrepancies Quitionnaire on 28 roleplay players. The results showed that as many as $64.2 \%$ of subjects experienced high self discrepancy and $30 \%$ did not experience self discrepancy.
\end{abstract}

\section{Keywords: Self Discrepancy, Roleplayer, K-Pop.}

Abstrak. Roleplay diartikan sebagai kegiatan dimana seseorang memparodikan idola mereka. Seorang roleplayer ada yang memainkan karakter buatannya sendiri. Dalam permainan tersebut setiap orang tidak mengetahui identitas asli masing-masing, sehingga seseorang harus membuat karakternya sendiri. Pada komunitas ini terdapat beberapa pemain yang menggunakan karakter berjenis kelamin laki-laki padahal di dunia nyata ia seorang perempuan. Kebanyakan dari mereka berusia 18-24 tahun dengan pekerjaan sebagai mahasiswa dan pegawai swasta. Roleplayer pada penelitian ini telah bermain di komunitas ini lebih dari lima tahun dan diri asli yang sangat berbeda dengan diri virtualnya. Dalam kondisi tersebut terjadi ketidakcocokan persepsi antara Actual Self, Ideal Self, Ought Self dan Virtual Self, hal ini disebut sebagai Self Discrepancy (Higgins, 2000). Penelitian ini menggunakan metode analisis deskriptif untuk mengetahui bagaimana Self Discrepancy pada Roleplayer K-Pop di komunitas Entertaiment ' $x$ '. Alat ukurnya menggunakan kuisioner (SDQ) Self Discrepancies Quitionnaire pada 28 pemain roleplay. Hasil penelitian menunjukkan bahwa sebanyak $64.2 \%$ subjek mengalami self discrepancy tinggi dan 30\% tidak mengalami self discrepancy.

Kata Kunci: Self Discrepancy, Roleplayer, K-Pop. 


\section{A. Pendahuluan}

Setiap media sosial memiliki fungsi tersendiri. Selain sarana sebagai penyampai informasi dan penyampai pesan yang cepat, juga berfungsi sebagai sarana hiburan. Hiburan dan fasilitas yang diberikan media sosial tersebut dapat digunakan oleh individu ataupun komunitas. Sekarang ini komunitas dalam media sosial sangat mudah dijumpai sesuai dengan kelebihan komunitasnya masing-masing. Salah satu komunitas yang berada di media sosial twitter adalah Roleplay. Roleplay adalah kegiatan dimana seorang pemain memparodikan idola mereka. Pemain roleplayer juga umumnya memerankan idolanya dengan karakter yang dibuat sendiri oleh mundane (orang asli dibalik karakter). Dalam memainkan Roleplay, mereka membuat sebuah akun di media sosial, dengan menggunakan profil, data diri, foto idola mereka dan membuat latar belakang idolanya dengan karakter yang berbeda (Nurul, 2017). Kemudian dalam akun para Roleplayer (sebutan pemain Roleplay) mereka akan berperan wajah idola mereka namun para pemain membuat latar belakang karakternya sendiri, hingga karakternya terasa hidup didalam permainan tersebut. Banyak sekali komunitas Roleplayer di dalam media sosial Twitter. Salah satu komunitas terbesar yang masih aktif hingga saat ini adalah Entertaiment ' $\mathrm{x}$ '.

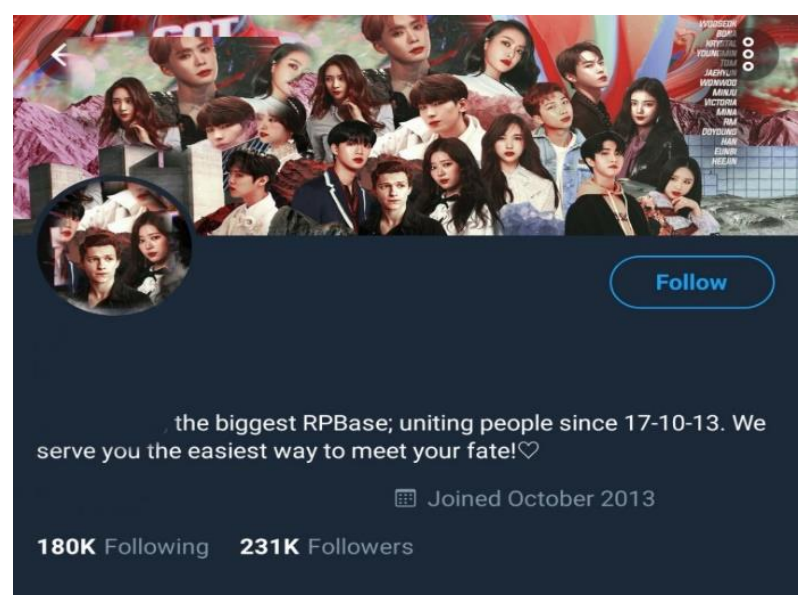

Gambar 1. Komunitas Roleplayer

Pada komunitas Entertaiment ' $x$ ' terdapat 400 pengguna akun Roleplayer aktif hingga saat ini. Pengguna yang aktif tersebut berusia $14-24$ tahun. Dari 87 anggota Roleplayer sebanyak $45 \%$ berusia 18-24 tahun. Setelah dilakukan wawancara terhadap 13 orang member Entertaiment ' $x$ ' dengan usia 18-24 tahun umumnya, mereka orang yang tidak mudah bersosialisasi di dunia nyata. Subjek mengatakan bahwa dirinya sulit beradaptasi dengan lingkungan, seperti sulit bertemu dengan orang baru karena merasa canggung apabila sedang berada di lingkungan pertemanan, sehingga subjek menjadi orang yang pendiam, lebih sering sendirian dan tidak ada keinginan mencari teman. Roleplayer juga menjadi tidak nyaman apabila berada dalam situasi yang mengharuskan dirinya berkomunikasi dengan orang lain, sehingga subjek menghindari situasi itu. Hal tersebut membuatnya menjadi tidak percaya diri didepan oranglain karena menurutnya oranglain sering memandang fisik terlebih dahulu. Berdasarkan latar belakang yang telah diuraikan, maka perumusan masalah dalam penelitian ini sebagai berikut: "Bagaimana gambaran Self Discrepancy pada Roleplayer K-Pop di Komunitas Entertaiment 'x'?'. Selanjutnya, tujuan dalam penelitian ini untuk mengenal Self Discrepancy pada diri Roleplayer di Entertaiment ' $x$ '. 


\section{B. Landasan Teori}

Menurut Tory Higgnis (2000), Self Discrepancy adalah adanya ketidakccokan persepsi individu terhadap empat self yaitu actual self, ideal self, ought self dan virtual self tersebut. Mengacu pada ketidakcocokan antara empat dimensi sebagai perbedaan diri. Perbedaan tersebut memiliki urutan yang dapat diprediksi yang dieskplorasi oleh Higgins dalam penelitian. Dia menemukan bahwa ketika diri actual, ideal, ought dan virtual self tidak cocok, dengan kata lain seseorang tidak hidup dengan cita-cita sendiri atau gagal mencapai impian kita, maka kita akan mengalami 'emosi yang terkait dengan kekecewaan' seperti kekecewaan, rasa malu dan bahkan mungkin depresi.

Meskipun ketidak sesuaian diri dapat dianggap sebagai suatu bentuk yang tidak konsisten, keyakinan dan sumber kenyamanan disebabkan oleh ketidaksesuaian dari empat dimensi tersebut. Ketika orang percaya mereka tidak dapat memenuhi beberapa tujuan yang seharusnya mereka dapatkan mereka akan merasakan kesedihan bahkan kekecewaan. Secara umum ada dua macam situasi psikologis negatif yang berhubungan dengan berbagai jenis keadaan emosional:

1. Tidak adanya hasil positif (diri actual yang diharapkan) yang terkait dengan penyimpangan emosi (ketidakpuasan, kekecewaan, kesedihan.)

2. Adanya hasil negative (actual yang diharapkan), yang dikaitkan dengan emosi yang terkait agitasi (ketakutan, ancaman, kegelisahan).

Self Discrepancy dapat terjadi saat seseorang berada dalam keadaan persepsi diri aktualnya berkebalikan jauh dengan padangan orang itu sendiri. Perbedaan ini kemudian mewakili situasi psikologis umum dengan adanya harapan atau keinginan untuk mencapai diri aktual yang sesungguhnya. Dengan demikian orang dapat diperkirakan rentan terhadap penyimpangan emosi. Lebih khusus lagi orang tersebut akan diprediksi rentan kekecewaan dan ketidakpuasan karna hal ini terkait dengan emosi yang dimiliki manusia. berikut;

Self Discrepancy memiliki empat dimensi di dalamnya, dimensinya adalah sebagai

1. Diri Aktual

Diri aktual adalah "diri yang sebenarnya", yang merupakan kondisi diri sekarang, mencakup kualitas baik dan buruk yang dimiliki. Kualitas baik merupakan persepsi psikologis positif terhadap diri kita dan kualitas buruk merupakan kualitas persepsi psikologis negatif yang ada pada diri.Diri aktual yang bermakna dapat mengakui kekuatan kita dan mengakui kelemahan kita.

2. Diri Ideal

Higgins berhipotesis bahwa seseorang juga memiliki "diri ideal", yang merupakan sikap diri yang kita inginkan di masa depan. Ini termasuk meningkatkan atau menambah sikap positif di dalam diri, dan itu berarti menghilangkan atau setidaknya mengurangi kualitas negatif yang dimiliki sekarang. Diri ideal adalah impian dan tujuan yang diidamkan.

3. Diri yang seharusnya

Berbeda dengan diri ideal, diri "seharusnya" adalah persepsi diri seseorang terhadap persepsi lingkungan mengenai dirinya. Diri yang seharusnya didasarkan pada persepsi kita tentang apa yang lingkungan pikirkan, lingkungan tersebut mencakup pada lingkungan keluarga dan pertemanan. Persepsi diri terhadap persepsi lingkungan ini dapat mempengaruhi perilaku seseorang di lingkungannya. Sehingga seseorang akan berusaha menyamakan persepsinya dengan persesi orang lain di lingkungannya.

4. Diri Virtual

Teori self discrepancy Higgins (1987) di dalamnya terdapat diri actual, ideal dan ought dan seharusnya dunia maya berhasil melampaui batas yang seseorang rasakan tentang realitas fisik, lalu muncullah domain ke empat yaitu virtual self. Istilah virtual self sudah digunakan oleh banyak peneliti (Behm-Morawitz, 2013 dalam Higgins, 2000) tanpa definisi yang sangat jelas atau umum. Namun, ini penting untuk dilakukan, 
karena mayoritas simpulan yang diambil dari studi sebelumnya tidak bisa secara langsung dibandingkan dan terkait satu sama lain, karena definisi yang berbeda dari konsep ini. Maka, makna diri virtual bahkan mungkin berbeda dari orang ke orang. Kegiatan virtual memungkinkan pemain mereka untuk mengembangkan avatar mereka tanpa terlalu banyak kendala dan rintangan. Namun, actual self adalah sebuah konsep yang secara khusus hadir dalam kehidupan nyata; dimana setiap tindakan secara langsung terkait dengan konsekuensi yang tidak mudah dihindari.

Kesenjangan yang besar antara diri aktual dan ideal dapat menghilangkan kepercayaan antara harapan dan mimpi, karena adanya persepsi negatif yang tidak setara antara kedua dimensi tersebut. Perbedaan antara ke empat dimensi tersebut, dapat membahayakan kesejahteraan emosional individu dan berdampak pada tingkat kebahagiaan, integrasi social dan kesejahteraan emosional individu. (Higgins. 2000).

Ketika semua dimensi menjadi lebih besar atau lebih kecil berjalan satu sama lain dan seimbang. Hal tersebut dapat memfasilitasi aktualisasi diri, berkembang dan memungkinkan individu untuk memenuhi potensi mereka (Rogers, 1961). Mengacu pada kombinasi diatas, pada sudut pandang lain ada dua situasi psikologis negatif dasar yang berhubungan dengan perbedaan daerah diri untuk dua sudut pandang bimbingan-diri. Kesenjangan diri yang berhubungan dengan dua situasi psikologis yang negatif tersebut adalah :

1. Sudut pandang diri sendiri dan orang lain (actual/ own self versus ideal self).

Dalam kesenjangan ini diterangkan bahwa jika orang memiliki kesenjangan antara keadaan tertentu dari atribut aktualnya dengan ideal self yang secara pribadi yang diinginkan atau keyakinan tentang harapan orang lain, maka akan mempengaruhi kondisi psikologis secara negatif. Gambaran kesenjangan diri ini berhubungan dengan keadaan emosional motivasional yang negatif (Higgins, 2000). Jenis situasi psikologis yang negatif tersebut berhubungan dengan kesedihan, kekecewaan, ketidakpuasan atau secara umum, kesedihan yang berhubungan dengan permasalahan emosionalmotivasional. Sebagai contoh misalnya adalah kesedihan, ketidakpuasan dan kekecewaan. Kondisi-kondisi tersebut dihasilkan dari penilaian terhadap harapan dan cita-cita yang tidak terpenuhi atau tidak adanya penguatan positif. Pada hal ini peran ought self akan berimbang dengan

2. Sudut pandang diri sendiri dan orang lain (actual/own self versus ought self).

Kesenjangan ini adalah kesenjangan antara keadaan tertentu dari atribut aktualnya dengan keadaan yang diyakini secara pribadi atau tugas dan kewajiban untuk mencapai beberapa pertimbangan orang dekat berupa tugas dan kewajibannya. Berbeda dengan situasi psikologis negatif diatas, kesenjangan ini menggambarkan situasi yang berhubungan dengan keadaan emosional-motivasional yang negatif. Jenis dari situasi psikologis yang negatif berhubungan dengan ketakutan, kekhawatiran, tegang, atau secara umum pergolakan yang berhubungan dengan Paradigma, permasalahan emosional-motivasional orang yang bersangkutan (Higgins, 2000).

Teori kesenjangan diri memuat dua asumsi mengenai diri pribadi seseorang yaitu motivational dan information processing. Pertama teori kesenjangan diri menganggap bahwa orang termotivasi untuk mencapai kondisi kesesuaian antara konsep dirinya dengan bimbingan diri yang relevan secara pribadi. Asumsi ini selanjutnya menerangkan bahwa orang termotivasi untuk membawa keadaan tertentunya kepada garis dengan beberapa keadaan akhir (end state) yang bernilai, motivasi ini adalah untuk mencapai kondisi kesesuaian antara diri aktual dengan bimbingan dirinya (Higgins, 2000). Asumsi kedua dari kesenjangan diri adalah hubungan antara dan diantara tipe yang berbeda dari gambaran keadaan diri menggambarkan macam yang berbeda dari situasi psikologis. Situasi psikologis tersebut berhubungan dengan perbedaan keadaan emosional-motivasional. Asumsi ini diperkuat dengan penjelasan yang mengemukakan bahwa reaksi orang pada perbuatannya tidak ditentukan semata-mata oleh pola dari perbuatan tersebut, tetapi juga oleh makna atau signifikansi perbuatan dirinya. 
Kesenjangan diri selain merupakan situasi psikologis yang bersifat motivasional juga merupakan struktur kognitif. Hal ini disebabkan bahwa kesenjangan diri melibatkan hubungan antara sifat pada keadaan diri yang sat $u$ dengan yang lainnya. Pemahaman yang dapat diperoleh adalah bahwa makna menjadi bagian alasan orang dalam mengerjakan sesuatu. Secara umum, ditegaskan bahwa situasi psikologis adalah sebuah fungsi dari peristiwa alami dan interpretasi orang terhadapnya (Higgins, 2000).

\section{Hasil Penelitian dan Pembahasan}

Berikut adalah kata-kata yang banyak muncul pada Self Discrepancy Quitionarre (Higgins, 2000) yang diberikan kepada subjek:

\begin{tabular}{|c|c|c|}
\hline $\mathrm{NO}$ & Dimensi & Kata sifat. \\
\hline 1 & Actual Self & $\begin{array}{ll}- & \text { Pesimis (12) } \\
- & \text { Pencemas (10) } \\
- & \text { Baik hati (8) } \\
- & \text { Emosional (8) } \\
- & \text { Sembrono (7) } \\
- & \text { Bimbang (6) } \\
- & \text { Keras kepala (6) } \\
- & \text { Pelamun (5) } \\
- & \text { Tidak menyenangkan (5) } \\
- & \text { Pemurung (5) } \\
- & \text { Malas (5) }\end{array}$ \\
\hline 2 & Ideal Self & $\begin{array}{ll}- & \text { Menyenangkan (10) } \\
- & \text { Optimis (9) } \\
- & \text { Dapat diandalkan (8) } \\
- & \text { Produktif (8) } \\
- & \text { Baik hati (7) } \\
- & \text { Rajin (7) } \\
- & \text { Mandiri (6) } \\
- & \text { Bersemangat (5) } \\
- & \text { Kreatif (5) }\end{array}$ \\
\hline 3 & Ought Self & $\begin{array}{ll}- & \text { Tidak percaya diri (11) } \\
- & \text { Sulit bergaul (10) } \\
- & \text { Pendiam (8) } \\
- & \text { Pelamun (8) } \\
- & \text { Pemurung(7) } \\
- & \text { Rajin }(7) \\
- & \text { Pesimis (6) } \\
- & \text { Tidak Menyenangkan (5) }\end{array}$ \\
\hline 4 & Virtual Self & $\begin{array}{ll}- & \text { Senang diperhatikan (14) } \\
- & \text { Ramah (10) } \\
- & \text { Menyenangkan (9) } \\
- & \text { Optimis (8) } \\
- & \text { Mudah bergaul (8) } \\
- & \text { Mudah berbaur (7) }\end{array}$ \\
\hline
\end{tabular}

\section{Gambar 2. Hasil Self Discrepancy Quitionarre}

Self Discrepancy Quitionarre merupakan alat ukur yang dirancang oleh Higgins (2000), alat ukur tersebut merupakan projective instrument dengan melampirkan isian, yang nantinya akan diisi oleh persepsi mengenai empat dimensi yang diisi oleh roleplayer. Berdasarkan data, dari 28 responden 
terjadi self discrepancy pada 64.2\% roleplayer. Kesenjangan ini menurut Higgins (2000) dijelaskan, yaitu keadaan dimana secara aktual roleplayer merasakan persepsi negatif terhadap dirinya. Dari data diketahui persepsi mengenai diri aktual roleplayer yang sering muncul adalah kata-kata pesimis, pencemas, baik hati, pelamun, bimbang, keras kepala, pemurung, dan malas. Dengan penggambaran yang diberikan oleh roleplayer mengenai dirinya, hal tersebut kebanyakan menggambarkan kesenjangan diri yang berhubungan dengan situasi psikologis yang negatif.

\section{Self Discrepancy Profil A.}

Berdasarkan hasil roleplayer yang memiliki actual self rendah, mempersepsikan dirinya bersenjangan dengan diri idealnya, Roleplayer mempersepsikan dirinya dengan diri aktual yang pesimis, pencemas, baik hati, emosional, sembrono, bimbang, keras kepala, pelamun, tidak menyenangkan, pemurung dan malas. Data tersebut menunjukkan persepsi emosi negatif, roleplayer yang memiliki diri aktual tersebut, banyaknya menggambarkan sebagai seorang yang pencemas, pesimis terhadap hal-hal yang menurutnya belum tentu dapat ia capai dan emosional dalam merespon suatu hal yang tidak sesuai dengan dirinya.

Diri aktual roleplayer tersebut terlalu berbeda dengan diri idealnya, yaitu ia gambarkan dirinya sebagai seorang yang harus optimis terhadap keinginannya yang belum terpenuhi termasuk cita-cita, lalu roleplayer juga ingin menyenangkan untuk orang lain, ia ingin lebih produktif tanpa membuang-buang waktu untuk hal yang tidak penting juga menjadi seorang yang dapat diandalkan oleh orang banyak. Hal tersebut dapat dikatakan bahwa subjek memiliki diri ideal yang tinggi. Diri ideal secara teoritis akan menghasilkan persepsi yang lebih tinggi dari diri aktual, tetapi pada fenomena ini roleplayer memiliki diri ideal yang jauh dari aktual dan tidak memiliki sumber informasi untuk mencapai diri idealnya.

Setelah itu roleplayer dengan self discrepancy tinggi memiliki ought self yang rendah, dalam artian roleplayer mempersepsikan lingkungannya berpersepsi negatif sesuai dengan actual self yang ia miliki. Ought self yang dipersepsikan menggambarkan bahwa seorang roleplayer dituntut untuk lebih percaya diri, lebih ramah, menyenangkan dan bersemangat lagi di lingkungannya. Hal tersebut menggambarkan lingkungan yang mengharapkan roleplayer dapat lebih berbaur juga dapat meningkatkan kualitas dirinya lagi. Roleplayer ini memiliki pekerjaan sebagai mahasiswa, maka lingkungan ought self yang di persepsikan olehnya adalah lingkungan di kampus bersama teman dan dosen. Menurut teori, diri kita seharusnya dapat berubah berdasarkan cara pikir pada lingkungan. Hal yang ditunjukan dari ought self tersebut dapat menimbulkan faktor emosional-motivasional yang membuat individu kesulitan mendapatkan penguat positif dari lingkungan.

Berdasarkan responden, terdapat roleplayer yang telah bekerja. dalam persepsinya mengenai diri aktual ia mempersepsikan bahwa dirinya sesuai dengan apa yang oranglain persepsikan. Menurutnya lingkungan tempat kerja tidak memberikan emotional motivational untuk dirinya mengembangkan diri aktualnya. secara aktual ia merasakan dirinya sebagai seorang yang tidak menyenangkan, pesimis, emosional dan sembrono. Hal tersebut menurutnya sangat sesuai dengan apa yang dipersepsikan oleh lingkungannya.

Berdasarkan data di atas subjek memenuhi beberapa faktor terjadinya self discrepancy yaitu dari lingkungan menggambarkan tidak adanya support yang mendorong roleplayer untuk lebih baik, dari faktor pertemanan, emosi positif, emosi negatif dan emosional-motivasional. (Higgins, 2000) Roleplayer mengalami keadaan psikologis yaitu emotional - motivational, faktor tersebut dapat membuat roleplay dapat merasakan rendah diri dengan diri aktualnya dan juga tidak mampu mewujudkan diri idealnya karena kurangnya support yang didapatkan dari ought self terhadap dirinya. Ia mempersepsikan lingkungan memberikannya tekanan terhadap tuntutan yang tidak bisa ia lakukan sehingga kemampuan mengembangkan diri idealnya tidak berkembang dan tidak adanya penguatan positif dari lingkungan.

\section{Self Discrepancy Profil B.}

Sebanyak $35.5 \%$ roleplayer di dalam komunitas entertainment ' $x$ ' tidak mengalami self discrepancy. Gambaran roleplayer ini dilihat dari diri aktual yang ia miliki, roleplayer merupakan seorang yang merasa dirinya kreatif, berpikiran terbuka, dapat diandalkan, mandiri. Roleplayer merasa dirinya seorang yang kreatif karena banyak ide-ide dan pemikiran 
yang membuatnya selalu terdorong membuat karya tulis, lalu ia berpeprsepsi bahwa dirinya juga seorang yang berpikiran terbuka, menurutnya ia mudah menerima kritikan orang lain dan senang berdiskusi dengan orang lain. Lalu mandiri, roleplayer sudah terbiasa melakukan semuanya sendiri termasuk pekerjaan sehari-harinya. Hal tersebut menerminkan emosi positif yang roleplayer persepsikan, namun menurut data roleplayer juga memiliki beberapa emosi negatif seperti pesimis dan keras kepala. Emosi negatif tersebut tidak terlalu mempengaruhi karena lebih banyak emosi positif yang sama. Diri aktual yang bermakna adalah saat individu dapat mengakui kekuatan dan kelemahannya (Higgins, 2000) sehingga hal tersebut dianggap wajar apabila ada hal negatif san positif bersamaan.

Menurut teori diri ideal pada umumnya akan selalu lebih baik dari diri aktual karena diri ideal kita adalah impian kita dan tujuan. Yang penting, diri ideal kita benar-benar berdasarkan apa yang kita inginkan (Higgins, 2000). Roleplayer mempersepsikan diri idealnya dengan ambisius, optimis, kreatif dan berpikiran terbuka. Ambisius tersebut muncul karena roeplayer ingin lebih mengeksplorasi dirinya dan mendapatkan peringkat yang baik dalam akademik. Dari data demografis roleplayer berusia 18-20 tahun yang berprofesi sebagai mahasiswa baru. Usia tersebut masih masuk ke dalam usia emerging adult, dimana roleplayer tidak termasuk muda ataupun dewasa. Dirinya sedang di masa semangat untuk mengejar masa depan dan eksplorasi diri agar lebih berkembang lagi. (Arnett, 2002).

Dilihat dari ought self, roleplayer yang berada di lingkungan kampus baru dengan teman-teman yang baru mempeprsepsikan bahwa lingkungannya berpersepsi dirinya seorang yang optimis, ambisius, dapat diandalkan dan peduli. Hal tersebut disampaikan secara tersirat oleh lingkungannya dan membuat dirinya membentuk motivasi positif untuk lebih mengembangkan lagi diri aktual yang ia miliki. Higgins menemukan bahwa ketika diri yang sebenarnya dan diri yang ideal tidak cocok - dengan kata lain, kapan kita tidak hidup sesuai dengan cita-cita kita sendiri atau kita gagal mencapai impian kita — kita akan mengalami "emosi yang terkait dengan kesedihan" seperti kekecewaan, rasa malu, rasa malu, dan bahkan mungkin depresi (Higgins, 1987). Roleplayer memiliki diri aktual dan ideal yang dikatakan cocok karena banyak kata yang sama dari ke empat dimensi tersebut. Sehingga, ia merasa lebih percaya diri akan adannya dorongan lingkungan.

Selain itu kata yang sering muncul pada karakter virtualnya adalah jujur, dapat diandalkan, ramah, mudah berbar dan ambisius. Roleplayer memainkan karakter dengan konsep, ia mengkonsep karakternya sesuai dengan ceritannya namun ternyata masih berdekatan sifatnya dengan diri aktual. Seperti ramah, seringnya ia bercengkrama dengan teman di dalam komunitas tersebut walaupun tidak terlalu mengenal ia akan mengobrol dengan ramah. Lalu, roleplayer juga berusaha selalu dapat diandalkan di dalam komunitas tersebut. Ia pernah menjabat menjadi admin juga dan mengetahui seluk-beluk komunitas tersebut. Baginya bermain roleplay merupakan hobi semata karena subjek sangat suka menulis. Disana biasanya ia akan menuliskan berbagai cerita bersambung yang menarik untuk dibaca orang.

Roleplayer yang tidak mengalami self discrepancy memiliki diri yang setara antara diri aktual yang masih dapat dikembangkan menjadi diri idealnya, juga adanya dukungan positif yang datang dari diri lingkungan di kampus teman-teman barunnya. Sehingga, bermain roleplay buatnya adalah sebuah hobi menulis saja dan mencari banyak teman. Menggunakan identitas virtual sebagai laki-laki selain untuk mencari perhatian lawan jenis menurutnya itu adalah sebuah usahanya untuk membuat karakter yang semmpurna untuk mendukung ceritanya.

\section{Kesimpulan}

Berdasarkan pembahasan Berdasarkan penelitian dan pembahasan yang telah dilakukan, dapat disimpulkan:

1. Sebanyak $64.2 \%$ mengalami Self Discrepancy yang tinggi dan mengalami indikasi adanya kecemasan dan kekhawatiran. Semakin lama roleplayer bermain di dalam dunia virtualnya maka semakin adanya ketidakcocokan persepsi antara actual self, ideal self, 
ought self dan virtual self.

2. Sebanyak $35.5 \%$ roleplayer tidak mengalami Self Discrepancy. Ia dapat mengembangkan Self-nya dengan baik dan dapat memanfaatkan bermain di komunitas entertainment ' $x$ ' sebagai hobi menulis dan tempatnya untuk mencari teman.

\section{Daftar Pustaka}

[1] Arnett, J. J. (2000). Emerging Adulthood: A Theory of Development From the Late Teens Through Twenties. American Psychologial Asociation , 55 (5), 469-480.

[2] Higgins, Tory E. 2000. Self-Discrepancy: A Theory Relating Self and Affect. New York University.

[3] Noor, H. (2009). PSIKOMETRI Aplikasi Dalam Penyusunan Instrumen Pengukuran Perilaku. Bandung: Jauhar Mandiri

[4] Kassiri, Nayerah. 2016. Comparison The Real Self, Idel Self and Ought Self in Adolecents With And Without Criminal History in Isfahan. Psychiatry and Behavioral Center.

[5] Kupersmidt, Janis B. 2001. Sosial Self Discrepancy: A Theory Relating Peer Problem and Maladusment.

[6] Marley, Selina (2014). The Virtual Self: Exploring the influence of virtual wordls on selfconcept and psychological well-being: a qualitative study. Positive Psychology and Technology. Universitet Twente.

[7] Simona, Sica. (2014). Virtual Identity: Risk or Resource? A study effects of using social network. University of Naples "Federico II", Italy.

[9] Riva, Gluseppe (2016). Psychology of Social Media: From Technology to Identity. De Gruyter.

[10] Picus, Tamar. (2009). An Investigation Into The Use Social Media \& Self Discrepancy:Who Are We Online?

[11] Nurul, Destevania. 2017. Konsep Diri Korean Roleplayer (Studi Fenomenologi pada Korean Roleplayer Dalam Dunia Virtual). Universitas Islam Bandung.

[12] Kim, K, H. Dkk. (2002). E-lifestyle and motives to use online games. Irish Marketing Review; ABI/INFORM Global pg. 71. 